\title{
Ground-dwelling spider assemblages in contrasting habitats in the central South African Grassland Biome
}

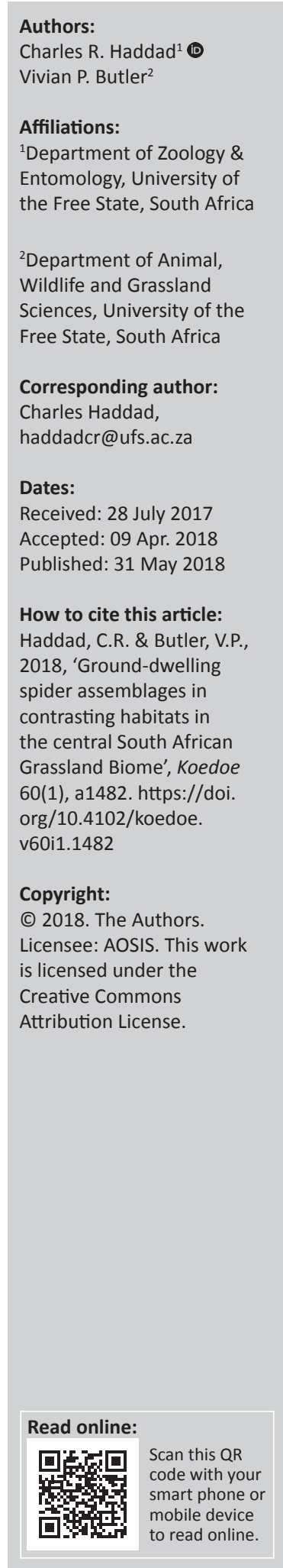

Background: Ground-dwelling spider assemblages in shrublands and cultivated pastures in the South African Grassland Biome have never been comprehensively studied.

Objectives: Epigeic spiders were collected in eight different habitats in the Amanzi Private Game Reserve in the Free State to determine assemblages of different vegetation types.

Methods: Three of the sampled habitats were contrasting low-lying shrublands; three were contrasting hill aspects (northern slope, southern slope and plateau) in the Buddleja salignaSearsia burchellii-Olea europaea africana subcommunity; one habitat was cultivated Digitaria eriantha pastures, and the last habitat was an area in and around a freshwater dam. Spiders were sampled by pitfall trapping in early spring (Sept. 2012), mid-summer (Jan. 2013), mid-autumn (Apr. 2013) and mid-winter (July 2013).

Results: A total of 2982 adult spiders were collected, representing 129 species and 33 families. Ammoxenidae was the most abundant family (40.85\%), followed by Gnaphosidae (21.26\%), Zodariidae (10.80\%) and Salticidae (10.26\%). Gnaphosidae was the most species-rich family (24.81\%), followed by Salticidae (13.18\%), Lycosidae $(11.63 \%)$ and Zodariidae $(6.20 \%)$. Spider activity densities and species richness did not differ significantly between habitats, although significant seasonal fluctuations were detected. The three hill aspects and cultivated $D$. eriantha pastures had the most distinct assemblages, while those of the three low-lying shrublands and freshwater dam showed considerable overlap.

Conclusions: Our results indicate that the aspect of hills has a significant effect in shaping spider assemblages, while the vegetation composition of shrublands is not strongly influential. The unique spider assemblages of cultivated $D$. eriantha pastures can be attributed to the absence of woody plants.

Conservation implications: This was the first study to investigate ground-dwelling spider assemblages in shrublands and cultivated pastures in the South African Grassland Biome. Our study confirms that hill aspects, shrublands and pastures harbour very different spider faunas. When identifying land for potential expansion or establishment of protected areas, conservation planners should ensure that the greatest diversity of vegetation units are included to optimise the conservation of biodiversity.

\section{Introduction}

In Africa, the Grassland Biome is largely limited to the central plateau of South Africa, Lesotho and parts of Swaziland (Mucina \& Rutherford 2006). It is characterised by extremely high plant biodiversity, second only to that of the Fynbos Biome (Low \& Rebelo 1996). Grasslands can be defined as a single-layered herbaceous plant community, with a few woody plants, which are usually restricted to specific habitats, including drainage lines and rocky hilltops (Carbutt et al. 2011). The Grassland Biome is one of the most transformed biomes in South Africa and is under continuous threat from cultivation, overgrazing and urban expansion (Bredenkamp \& Van Rooyen 1996). Only an estimated $2.04 \%$ to $2.80 \%$ of this biome is formally conserved (Carbutt et al. 2011; O'Connor \& Kuyler 2005), and therefore, effective management and conservation of private land is critical to protect its highly endemic fauna and flora (Wessels et al. 2003).

Although nearly 910 point localities have been sampled for spiders in South African grasslands, only 27 of these have more than 100 specimen records (Foord, Dippenaar-Schoeman \& Haddad 2011). Only as recently as three decades ago were the first ecological studies on spiders undertaken in the biome, focusing on the biodiversity of ground-dwelling (Haddad et al. 2015; Jansen et al. 2013; 
Lotz, Seaman \& Kok 1991; Van den Berg \& DippenaarSchoeman 1991), plant-dwelling (Dippenaar-Schoeman, Hamer \& Haddad 2011; Fourie et al. 2013; Haddad 2005; Neethling \& Haddad 2013), litter-dwelling (Butler \& Haddad 2011) and termitophilous assemblages (Haddad \& Dippenaar-Schoeman 2002, 2006). Different species are adapted to particular microhabitats within grasslands, either living on the ground, on grasses or on foliage of woody plants, with few species abundant in multiple strata (Haddad et al. 2013). Consequently, there is considerable scope for research on spider biodiversity, ecology and biology in this unique biome.

Only three of the aforementioned studies have investigated finer scale differences in spider assemblages associated with different plant species, notably litter-dwellers (Butler \& Haddad 2011) and foliage-dwellers (Fourie et al. 2013; Neethling \& Haddad 2013). However, assemblage structure in contrasting vegetation communities has so far only been investigated for grass-dwellers in structurally variable grasslands (Fourie et al. 2013).

All the pitfall trapping surveys listed above were conducted in open grasslands with sparse or absent woody vegetation, and spider assemblages in shrublands and woodlands remain largely unknown in this biome (Butler \& Haddad 2011). The aims of this study were (1) to sample grounddwelling spider assemblages in different plant communities (predominantly shrublands) to determine possible habitat associations of spider species; (2) assess how habitats affected the activity density and species richness of spiders; (3) determine seasonality of ground-dwelling spider assemblages, and (4) determine whether indicator species could be identified for any of the sampled habitats. Further, this study aims to add to the current knowledge base of ground-dwelling spider biodiversity in South Africa, for which relatively little information is currently available (Dippenaar-Schoeman et al. 2015; Janion-Scheepers et al. 2016).

\section{Research method and design Study area}

Amanzi Private Game Reserve (APGR) is located about $80 \mathrm{~km}$ north-east of Bloemfontein in the central Free State (Figure 1a) and falls within the summer rainfall region of central South Africa, with an average of approximately $475 \mathrm{~mm}$ of rainfall received annually (Butler 2017). The area experiences hot summers, with day temperatures sometimes between $35^{\circ} \mathrm{C}$ and $40{ }^{\circ} \mathrm{C}$ (averaging above $30^{\circ} \mathrm{C}$ ), and cold winters, with night temperatures frequently below freezing and day temperatures usually ranging between $15^{\circ} \mathrm{C}$ and $20^{\circ} \mathrm{C}$ (Butler 2017).

The study area is located in the Grassland Biome (Rutherford \& Westfall 1994), with the vegetation of the surrounding area being described as Dry Sandy Highveld Grassland (Bredenkamp \& Van Rooyen 1996) or Vaal-Vet Sandy Grassland (Mucina \& Rutherford 2006). The vegetation in APGR is, however, more representative of Winburg Grassy Shrubland, which occurs in a series of larger patches from Trompsburg through Bloemfontein and Winburg to Ventersburg (Mucina \& Rutherford 2006).

The landscape of this vegetation type consists of isolated hills, slopes and escarpments, creating habitats ranging from

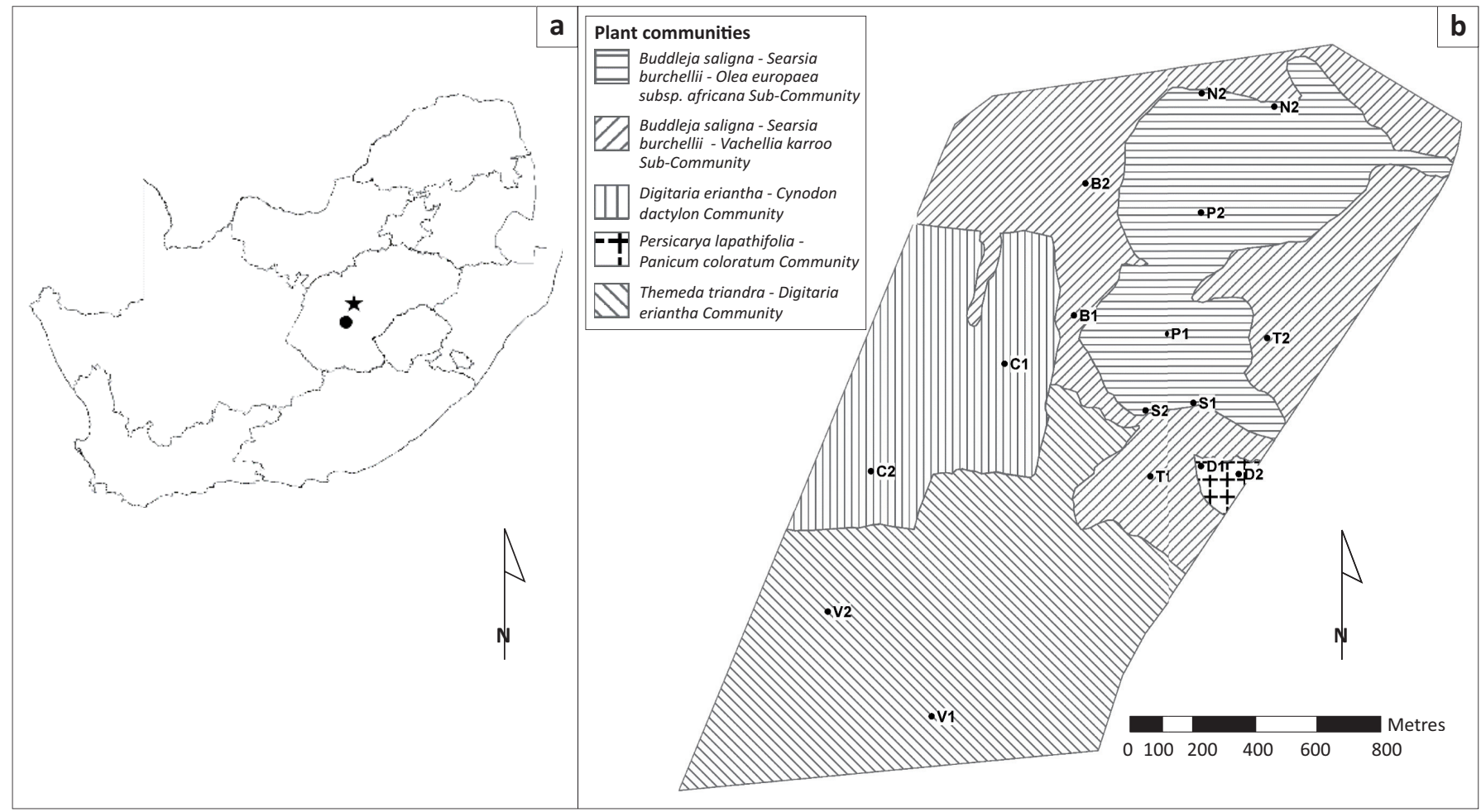

FIGURE 1: (a) Location of the Amanzi Private Game Reserve, Brandfort district, South Africa (star), north-east of Bloemfontein (circle) and (b) vegetation map of the western section of the Amanzi Private Game Reserve. 
open grassland to shrubland (Mucina \& Rutherford 2006). A comprehensive vegetation survey was conducted in the western section of APGR, and details of the community composition in this part of the reserve are provided in Butler (2017).

Based on the results of the vegetation survey, spiders were collected in eight different habitats representing four plant communities (Table 1; Figure 1b). In the Buddelja salignaSearsia burchellii community, two different subcommunities were sampled, one of which included three habitats associated with the northern and southern slopes and plateau of a hill (Buddleja saligna-Searsia burchellii-Olea europaea africana subcommunity), and the second including two habitats, one dominated by Searsia burchellii and the other by Tarchonanthus camphoratus (Buddleja saligna-Searsia burchelliiVachellia karroo subcommunity). The remaining three habitats sampled were the Themeda triandra-Digitaria eriantha community, which was dominated in the woody layer by Vachellia karroo; cultivated D. eriantha pastures (Digitaria eriantha-Cynodon dactylon community); and an area in and around a freshwater dam (Persicaria lapathifolia-Panicum coloratum community). The latter two communities had little or no plants contributing to the woody layer (Table 1).

\section{Spider sampling}

Two sites were sampled in each habitat, with at least $100 \mathrm{~m}$ separating them to avoid pseudoreplication. Five pitfall traps were placed $5 \mathrm{~m}$ apart in a straight line at each site. A soil auger was used for drilling holes, and plastic buckets $10 \mathrm{~cm}$ in diameter were used as pitfall traps. Ethylene glycol $(100 \mathrm{~mL})$ was added to each pitfall trap to preserve terrestrial arthropods for later identification. Collected material was removed and the pitfall traps refilled at the end of each month, from the start of September 2012 (early spring) to the end of August 2013 (end of winter). The sampled material was sorted in the laboratory and all arachnids were extracted from the samples and preserved in $70 \%$ ethanol. Following identification and tallying of adult spiders, material was deposited in the National Collection of Arachnida at the ARC-Plant Protection Research in Pretoria, South Africa.

Although spiders were sampled for a full year, several sampling months represented incomplete sampling efforts as a result of flooding of the pitfall traps at some sites following heavy rains, or damage caused to pitfall traps by large herbivorous mammals or vervet monkeys. To ensure that sampling effort was equal between habitats, we opted to provide data for 1 month in each season for which all sites had a complete sampling effort: early spring (September 2012), mid-summer (January 2013), mid-autumn (April 2013) and mid-winter (July 2013). Only adult spiders were included in the analysis.

\section{Statistical analysis}

We calculated the estimated species richness for each habitat using the equation:

$S_{\text {Chaol }}=S_{\text {obs }}+\left(F_{1}^{2} / 2 F_{2}\right)$,

where the number of species represented by a single individual (i.e. singletons) and two individuals only (i.e. doubletons) are represented by $F_{1}$ and $F_{2^{\prime}}$ respectively (Chao 1984). Chao1 is an estimator calculated using the available abundance data and is a function of the ratio between the singletons and doubletons in the data. With an increase in the number of samples, an accumulation curve reaches an asymptote when all species in the community are represented by at least two individuals.

We calculated sampling completeness as the ratio of the observed species richness $\left(S_{\text {obs }}\right)$ and the Chao1-estimated species richness $\left(S_{\text {Chaol }}\right)$ (e.g. Cardoso et al. 2008; Scharff et al. 2003; Sørensen, Coddington \& Scharff 2002).

TABLE 1: Detailed description of plant communities in each of the habitats sampled in the Amanzi Private Game Reserve from September 2012 to August 2013.

\begin{tabular}{|c|c|}
\hline Plant community & Habitat abbreviation and brief description \\
\hline \multicolumn{2}{|c|}{ Buddleja saligna - Searsia burchellii Community } \\
\hline \multirow[t]{3}{*}{$\begin{array}{l}\text { Buddleja saligna-Searsia } \\
\text { burchellii - Olea europaea africana } \\
\text { subcommunity }\end{array}$} & $\begin{array}{l}\text { S (Olea europaea closed evergreen } \\
\text { shrubland - situated on the southern } \\
\text { slopes) }\end{array}$ \\
\hline & $\begin{array}{l}\text { N (Olea europaea closed evergreen } \\
\text { shrubland - situated on the northern } \\
\text { slopes) }\end{array}$ \\
\hline & $\begin{array}{l}\text { P (Olea europaea closed evergreen } \\
\text { shrubland - situated on the plateaus) }\end{array}$ \\
\hline \multirow[t]{2}{*}{$\begin{array}{l}\text { Buddleja saligna-Searsia } \\
\text { burchellii - Vachellia karroo } \\
\text { subcommunity }\end{array}$} & $\begin{array}{l}\text { B (Searsia burchellii closed evergreen } \\
\text { shrubland - situated on the lower lying } \\
\text { flats) }\end{array}$ \\
\hline & $\begin{array}{l}\text { T (Tarchonanthus camphoratus closed } \\
\text { evergreen shrubland - situated on the } \\
\text { lower lying flats) }\end{array}$ \\
\hline \multicolumn{2}{|c|}{ Digitaria eriantha - Cynodon dactylon Community } \\
\hline & C (Cultivated Digitaria eriantha pastures) \\
\hline \multicolumn{2}{|c|}{ Persicaria lapathifolia - Panicum coloratum Community } \\
\hline & $\mathrm{D}$ (Freshwater dam) \\
\hline \multicolumn{2}{|c|}{ Themeda triandra-Digitaria eriantha Community } \\
\hline & $\begin{array}{l}\text { V (Vachellia karroo open deciduous } \\
\text { shrubland - situated on the lower } \\
\text { lying flats) }\end{array}$ \\
\hline
\end{tabular}

The herbaceous layer of this plant community was dominated by Aristida canescens, Panicum maximum and Themeda triandra, with the woody layer dominated by Olea europaea africana, Buddleja saligna, Searsia burchellii, Tarchonanthus camphoratus and Searsia ciliata

escription of plant community

\section{slopes) \\ Buddleja saligna-Searsia burchellii-Olea burchellii - Vachellia karroo subcommunity flats) $\mathrm{T}$ (Tarchonanthus camphoratus closed
evergreen shrubland - situated on the Community}

The herbaceous layer of this plant community was dominated by Aristida adscensionis, Cynodon hirsutus, Themeda triandra, Sporobolus fimbriatus and Eragrostis lehmanniana, with the woody layer dominated by Searsia burchellii, Buddleja saligna, Tard
camphoratus, Vachellia karroo, Asparagus suaveolens and Searsia ciliata

The herbaceous layer of this plant community is dominated by Digitaria eriantha, with only a few scattered Vachellia karroo saplings present in the woody layer

The herbaceous layer of this plant community was dominated by Persicaria lapathifolia and Panicum coloratum, with no trees or shrubs present

The herbaceous layer of this plant community was dominated by Themeda triandra, Sporobolus fimbriatus and Digitaria eriantha, with the woody layer dominated by the deciduous tree Vachellia karroo 
Chao and Jost (2012) proposed the use of coverage-based rarefaction and extrapolation to assess community richness and sampling effort. They defined sample coverage as the proportion of the total number of individuals in a community that belong to the species represented in the sample. Subtracting the sample coverage from unity gives the proportion of the community belonging to as yet unsampled species, which they referred to as the 'coverage deficit'. This can be inferred as the likelihood that a new, previously unsampled species will be found if the sample was increased by one individual (Chao \& Jost 2012). Coverage for each habitat and for the total spider assemblage was calculated using the following equation:

$C n=1-f_{1} / n\left[(n-1) f_{1} /(n-1) f_{1}+2 f_{2}\right]$,

where $n$ represents the number of individuals in the sample and $f_{1}$ and $f_{2}$ represent the number of singleton and doubleton species, respectively. Chao and Lee (1992) proposed that an estimated coverage value should be at least $50 \%$, that is, 0.5 .

Inventory completeness was analysed in Paleontological Statistics (PAST) version 2.07 using the sample rarefaction function, which implements the 'Mao tau' analytical procedure, with standard errors indicated as $95 \%$ confidence intervals on the resulting graphs. We produced curves for each of the habitats, as well as the for the whole spider assemblage.

Using PAST versions 2.07 and 3.06 (Hammer, Harper \& Ryan 2001), we calculated whether the abundance and species richness of spiders differed between the eight habitats and also whether these parameters varied seasonally, using linear multivariate regression. In each analysis, habitats and samples were used as independent variables. Because count data follows a Poisson distribution, values were log-transformed prior to analysis to approach a normal distribution.

We then determined whether the two sites from each habitat sampled similar spider assemblages by performing a twodimensional non-metric multidimensional scaling (NMDS), based on a Bray-Curtis similarity matrix. Ideally, the stress value of an NMDS should be lower than 0.2 ; otherwise, the resulting diagram needs to be interpreted with caution (Clarke 1993). Further, we performed a cluster analysis using the cluster function and unweighted pair-group average algorithm (Clarke \& Warwick 2001). In both analyses, the pooled data from each of the 16 sampling sites were used. Further, a permutational multivariate analysis of variance (PERMANOVA) was performed to test for differences in assemblages between the eight habitats, using the BrayCurtis distance measure and 10000 permutations. These analyses were carried out in PAST version 2.07.

Lastly, we attempted to identify indicator spider species, which are considered to be characteristic of a particular habitat. Indicator values were obtained by multiplying a species' relative abundance in a particular habitat, expressed as a percentage of its total abundance, with its relative frequency of occurrence in that particular habitat, that is, proportion of samples in which a species was collected (Dufrene \& Legendre 1997). Thus, a species' specificity (narrow association with a particular habitat) and fidelity (frequency of occurrence in that habitat) is expressed as a percentage that can be compared with other species in the sampled habitats (Dufrene \& Legendre 1997). A high indicator value illustrates a high affiliation of a species to a particular habitat, with a suitable benchmark of $70 \%$ being suggested (e.g. Haddad et al. 2010; McGeoch, Van Rensburg \& Botes 2002; Van Rensburg et al. 1999).

\section{Ethical consideration}

Permission to collect arachnids in the Free State province was obtained from the Free State Department of Economic Development, Tourism and Environmental Affairs.

\section{Results}

A total of 2982 adult spiders were collected, representing 129 species and 33 families (Table 2; Appendix 1). Ammoxenidae was the dominant family $(n=1218,40.85 \%)$, followed by Gnaphosidae $(n=634,21.26 \%)$, Zodariidae $(n=322,10.80 \%)$

TABLE 2: Family activity density and species richness of ground-dwelling spiders sampled by pitfall trapping from eight habitats in the Amanzi Private Game Reserve.

\begin{tabular}{|c|c|c|c|c|}
\hline \multirow[t]{2}{*}{ Family } & \multicolumn{2}{|c|}{ Activity density } & \multicolumn{2}{|c|}{ Species richness } \\
\hline & Total & $\%$ & Total & $\%$ \\
\hline Agelenidae & 18 & 0.60 & 1 & 0.78 \\
\hline Amaurobiidae & 37 & 1.24 & 2 & 1.55 \\
\hline Ammoxenidae & 1218 & 40.85 & 1 & 0.78 \\
\hline Araneidae & 2 & 0.07 & 1 & 0.78 \\
\hline Caponiidae & 35 & 1.17 & 1 & 0.78 \\
\hline Clubionidae & 2 & 0.07 & 1 & 0.78 \\
\hline Corinnidae & 14 & 0.47 & 3 & 2.33 \\
\hline Ctenizidae & 6 & 0.20 & 2 & 1.55 \\
\hline Cyrtaucheniidae & 21 & 0.70 & 5 & 3.88 \\
\hline Dictynidae & 1 & 0.03 & 1 & 0.78 \\
\hline Gnaphosidae & 634 & 21.26 & 32 & 24.81 \\
\hline Hahniidae & 3 & 0.10 & 2 & 1.55 \\
\hline Hersiliidae & 3 & 0.10 & 1 & 0.78 \\
\hline Idiopidae & 9 & 0.30 & 2 & 1.55 \\
\hline Linyphiidae & 1 & 0.03 & 1 & 0.78 \\
\hline Lycosidae & 206 & 6.91 & 15 & 11.63 \\
\hline Migidae & 5 & 0.17 & 1 & 0.78 \\
\hline Oonopidae & 4 & 0.13 & 2 & 1.55 \\
\hline Orsolobidae & 6 & 0.20 & 1 & 0.78 \\
\hline Oxyopidae & 14 & 0.47 & 2 & 1.55 \\
\hline Palpimanidae & 25 & 0.84 & 3 & 2.33 \\
\hline Philodromidae & 16 & 0.54 & 5 & 3.88 \\
\hline Phyxelididae & 11 & 0.37 & 1 & 0.78 \\
\hline Phrurolithidae & 4 & 0.13 & 1 & 0.78 \\
\hline Prodidomidae & 6 & 0.20 & 3 & 2.33 \\
\hline Salticidae & 306 & 10.26 & 17 & 13.18 \\
\hline Segestriidae & 1 & 0.03 & 1 & 0.78 \\
\hline Selenopidae & 1 & 0.03 & 1 & 0.78 \\
\hline Sparassidae & 1 & 0.03 & 1 & 0.78 \\
\hline Theridiidae & 26 & 0.87 & 3 & 2.33 \\
\hline Thomisidae & 20 & 0.67 & 6 & 4.65 \\
\hline Trachelidae & 4 & 0.13 & 2 & 1.55 \\
\hline Zodariidae & 322 & 10.80 & 8 & 6.20 \\
\hline Total & 2982 & 100.00 & 129 & 100.00 \\
\hline
\end{tabular}


TABLE 3: Summary of actual and estimated species richness of ground-dwelling spiders sampled by pitfall trapping from eight habitats in the Amanzi Private Game Reserve.

\begin{tabular}{|c|c|c|c|c|c|c|c|c|c|}
\hline Habitat & B & C & D & $\mathbf{N}$ & $\mathbf{P}$ & 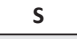 & $\mathrm{T}$ & $\mathbf{v}$ & Total \\
\hline$S_{\text {obs }}$ & 44 & 45 & 34 & 44 & 41 & 43 & 44 & 48 & 129 \\
\hline Singletons $\left(f_{1}\right)$ & 16 & 20 & 18 & 18 & 19 & 22 & 25 & 22 & 39 \\
\hline Doubletons $\left(f_{2}\right)$ & 9 & 4 & 5 & 8 & 6 & 6 & 5 & 8 & 20 \\
\hline$S_{\text {Chao1 }}$ & 58.22 & 95.00 & 66.40 & 64.25 & 71.08 & 83.33 & 106.50 & 78.25 & 167.03 \\
\hline Total abundance $(n)$ & 296 & 1480 & 156 & 177 & 183 & 276 & 161 & 253 & 2982 \\
\hline Coverage $(\mathrm{C} n)$ & 0.95 & 0.99 & 0.89 & 0.90 & 0.90 & 0.92 & 0.85 & 0.91 & 0.99 \\
\hline Sample completion $\left(S_{\text {obs }} / S_{\text {chao1 }}\right)$ & 0.76 & 0.47 & 0.51 & 0.68 & 0.58 & 0.52 & 0.41 & 0.61 & 0.77 \\
\hline
\end{tabular}

Habitat abbreviations: B, Searsia burchellii closed evergreen shrubland; C, cultivated Digitaria eriantha pastures; D, freshwater dam; N, Olea europaea closed evergreen shrubland on northern slopes of hill; $;$, O. europaea closed evergreen shrubland on plateau of hill; S, O. europaea closed evergreen shrubland on southern slope of hill; T, Tarchonanthus camphoratus closed evergreen shrubland; V, Vachellia karroo open deciduous shrubland.

and Salticidae $(n=306,10.26 \%)$. Ammoxenus amphalodes Dippenaar \& Meyer, 1980 strongly dominated the fauna overall ( $n=1218,40.85 \%)$, largely because of its extremely high activity densities in the cultivated $D$. eriantha pastures, where it represented $66.15 \%$ of the fauna. Ranops sp. (7.38\%) was the second most abundant species. Other common species include Proevippa sp. 1 (4.33\%), Phlegra karoo Wesołowska, 2006 (3.66\%), Zelotes sclateri Tucker, 1923 (3.66\%) and Drassodes sp. 2 (3.29\%).

Gnaphosidae was the most species-rich family (32 spp., 24.81\%), followed by Salticidae (17 spp., 13.18\%), Lycosidae (15 spp., 11.63\%) and Zodariidae (8 spp., 6.20\%). Total species richness was quite similar between habitats, ranging between 34 and 48 species. However, Chao1-estimated species richness varied considerably, between 58 and 106 species per habitat, with the total ground-dwelling assemblage in the sampled habitats estimated at 167 species (Table 3 ). Although coverage values were above 0.85 for all the habitats, sample completion was much more variable (0.41-0.76), with 0.77 for the total assemblage (Table 3). This pattern was confirmed by the sample rarefaction curve for the whole spider assemblage (Figure 2a), which approached an asymptote but did not level out, indicating that the majority of the ground-dwelling species in the sampled habitats had been collected. However, none of the habitats' rarefaction curves approached an asymptote (Figures $2 \mathrm{~b}-\mathrm{i}$ ), indicating that a considerable portion of the fauna of each was still unsampled. Because open grasslands were not sampled in this study, it could be expected that the total species richness at APGR may further exceed this projected value of 167 species.

Nearly half of all the spiders $(n=1480,49.63 \%)$ were collected from the two cultivated $D$. eriantha pasture sites; indeed, spider numbers in this habitat were exactly five times higher than the habitat with the second highest activity densities, Searsia burchellii closed evergreen shrubland $(n=296)$. However, linear multivariate regression showed no significant differences between habitats in log-transformed spider activity densities $\left(F_{2,61}=1.125, p=0.3313\right)$ or species richness $\left(F_{2,61}=0.3105, p=0.7343\right)$.

Linear multivariate regression showed that there was significant seasonality across all sites in log-transformed spider activity densities $\left(F_{2,61}=8.388, p=0.0006\right)$, with summer and spring activity densities clearly much higher than those of the colder seasons (Figure 3a). Species richness showed a similar pattern $\left(F_{2,61}=13.72, p<0.0001\right)$, although spring and summer species richness was very similar (Figure $3 b$ ), although markedly higher than autumn and winter species richness.

Spider assemblages showed some interesting patterns. Not surprisingly, the assemblages of the cultivated D. eriantha pasture sites were the most distinct and showed the greatest similarity to one another compared to all the other habitat site-pairs. Among the remaining seven habitats, only the three habitats associated with the hill had their paired sites grouping together (Figures $4 \mathrm{a}, \mathrm{b}$ ). There was considerable overlap in the assemblages of the lower lying shrubland types and the dam, with most site-pairs not grouping close together (Figure $4 \mathrm{~b}$ ). These results were supported by the PERMANOVA analysis, which showed highly significant differences between the spider assemblages in the sampled habitats (pseudo- $F=2.614, p<0.0001$ ). Particularly, the pairwise post hoc comparisons showed significant differences in assemblages between the cultivated pastures $(p<0.0007)$, plateau $(p<0.0128)$ and southern slope $(p<0.0105)$ and all the other habitats (Table 4 ). For the other habitats, several other paired habitats were also significantly different from each other, although the assemblages of the freshwater dam and Searsia burchellii closed evergreen shrubland had the fewest significant paired values, confirming their assemblage overlap with other habitats (Table 4).

Of the eight habitats sampled, indicator species with a percentage value $>70 \%$ were only found in one of the habitats, with $A$. amphalodes (80.38\%) and Ranops sp. (77.95\%) both being indicator species for the cultivated $D$. eriantha pastures. Of the remaining species, only three had indicator values $>50.00 \%$ : Setaphis browni (Tucker, 1923) $(62.50 \%)$ in the northern slope sites, Diores poweri Tucker, 1920 (66.18\%) in the plateau sites and Proevippa sp. 1 (58.72\%) for the southern slopes.

\section{Discussion}

Previous studies on ground-dwelling spiders in the Grassland Biome have focused on open grasslands, while the shrubland faunas have received little attention (Butler \& Haddad 2011). In this study, the first focused on shrubland habitats and cultivated pastures in the grasslands of central South Africa, the hill-associated habitats and cultivated $D$. eriantha pastures had the most distinct assemblages, while those of the lower 




FIGURE 2: Sample rarefaction curves (Mao tau) with 95\% confidence intervals for ground-dwelling spiders sampled in the Amanzi Private Game Reserve from September 2012 to August 2013: (a) all habitats combined; (b) Searsia burchellii closed evergreen shrubland; (c) cultivated Digitaria eriantha pastures; (d) freshwater dam; (e) Olea europaea closed evergreen shrubland on northern slopes of hill; (f) O. europaea closed evergreen shrubland on plateau of hill; (g) O. europaea closed evergreen shrubland on southern slope of hill; (h) Tarchonanthus camphoratus closed evergreen shrubland; and (i) Vachellia karroo open deciduous shrubland.

lying shrublands and freshwater dam showed considerable overlap and often lacked clear distinction. The sample completion values varied between 0.41 and 0.76 for each habitat, which suggests that further sampling is necessary for a better representation of the species richness of those habitats with sample completion $<0.5$. However, had the data from the other months sampled, but not included in this analysis, been incorporated into this study, then it is quite likely that this threshold value would have been exceeded in all the habitats.
Our results indicate that the aspect of hillside habitats has a strong influence in shaping assemblages. This could be because of the northern slopes getting more exposure to direct sunlight compared to the southern slopes. Southern slopes have denser vegetation cover in the woody layer, with especially Olea europaea africana providing a lot more shade. Assemblages of the plateau are also very unique, which can possibly be attributed to the differences in the herbaceous layer and slope of the habitat. We would propose conducting 


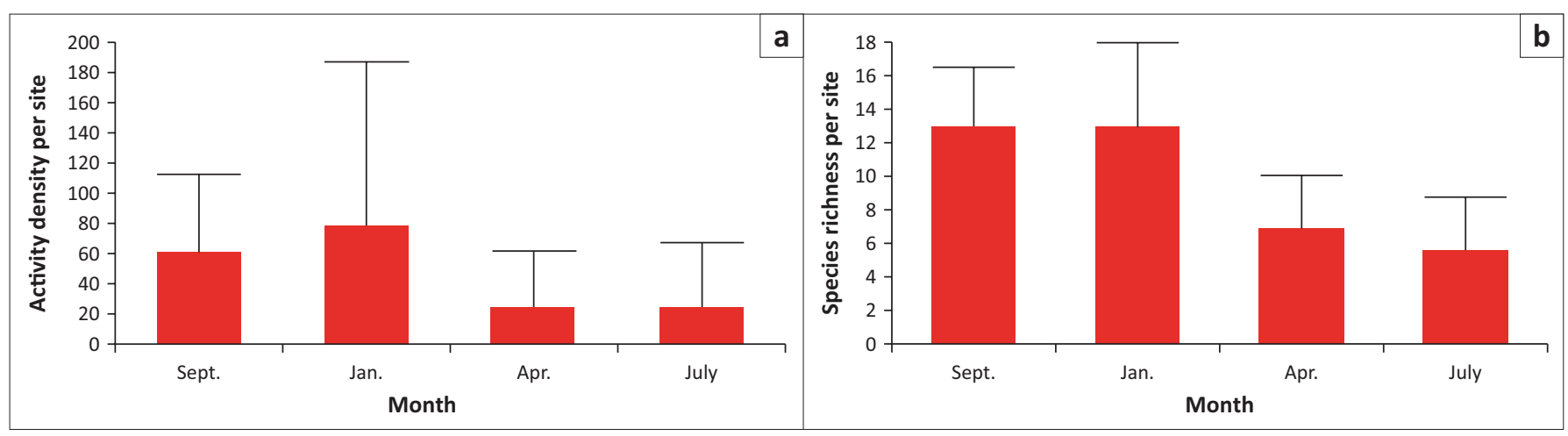

FIGURE 3: Seasonal variation in mean \pm SD of (a) activity densities and (b) species richness of ground-dwelling spiders across 16 sites (eight habitats) sampled in the Amanzi Private Game Reserve.

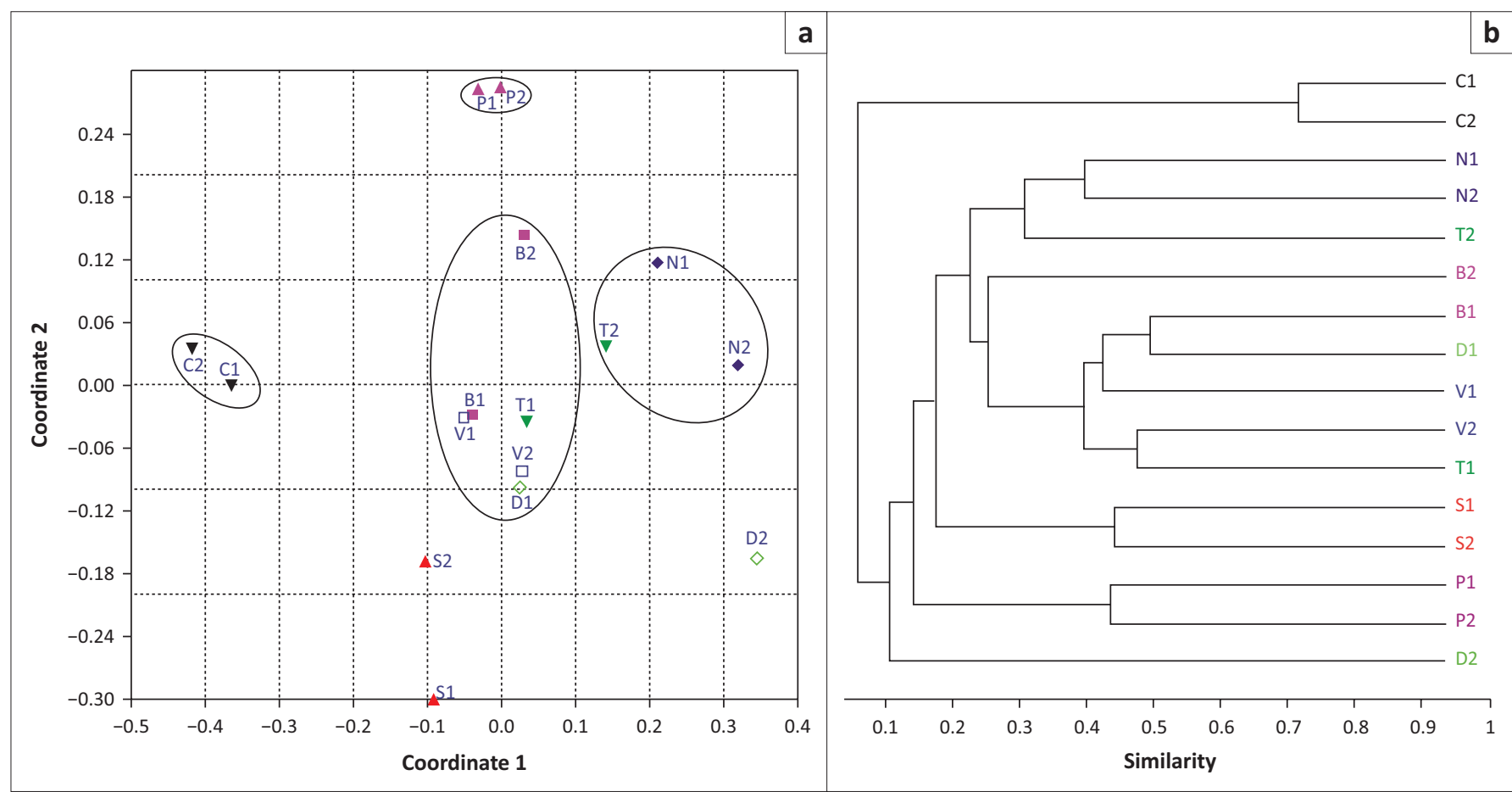

FIGURE 4: (a) Non-metric multidimensional scaling plot and (b) cluster analysis dendrogram using unweighted pair-group average algorithm of ground-dwelling spider assemblages sampled from eight habitats in the Amanzi Private Game Reserve. Analyses are based on a Bray-Curtis dissimilarity matrix using untransformed data. Habitat abbreviations: B, Searsia burchellii closed evergreen shrubland; C, cultivated Digitaria eriantha pastures; D, freshwater dam; N, Olea europaea closed evergreen shrubland on northern slopes of hill; $\mathrm{P}, \mathrm{O}$. europaea closed evergreen shrubland on plateau of hill; $\mathrm{S}$, $\mathrm{O}$. europaea closed evergreen shrubland on southern slope of hill; $\mathrm{T}$, Tarchonanthus camphoratus closed evergreen shrubland; V, Vachellia karroo open deciduous shrubland.

TABLE 4: Post hoc $p$-values calculated from permutational multivariate analysis of variance analysis of spider assemblages associated with eight habitats in the Amanzi Private Game Reserve.

\begin{tabular}{|c|c|c|c|c|c|c|c|c|}
\hline Habitat & B & C & D & $\mathrm{N}$ & $\mathbf{P}$ & $S$ & $T$ & v \\
\hline C & 0.0004 & - & - & - & - & - & - & - \\
\hline D & 0.4726 & 0.0001 & - & - & - & - & - & - \\
\hline$N$ & 0.1235 & $<0.0001$ & 0.2274 & - & - & - & - & - \\
\hline$P$ & 0.0096 & 0.0003 & 0.0016 & 0.0023 & - & - & - & - \\
\hline$S$ & 0.0021 & 0.0007 & 0.0017 & 0.0008 & 0.0005 & - & - & - \\
\hline $\mathrm{T}$ & 0.3905 & 0.0002 & 0.5668 & 0.2130 & 0.0128 & 0.0071 & - & - \\
\hline V & 0.2097 & 0.0002 & 0.0641 & 0.0028 & 0.0069 & 0.0105 & 0.4452 & - \\
\hline
\end{tabular}

Note: Values in bold indicate significant differences between habitats.

Habitat abbreviations: B, Searsia burchellii closed evergreen shrubland; C, cultivated Digitaria eriantha pastures; D, freshwater dam; N, Olea europaea closed evergreen shrubland on northern slopes of hill; P, O. europaea closed evergreen shrubland on plateau of hill; S, O. europaea closed evergreen shrubland on southern slope of hill; T, Tarchonanthus camphoratus closed evergreen shrubland; V, Vachellia karroo open deciduous shrubland.

a large-scale survey of various hills in central South Africa to determine whether each aspect of these hills (including east and west that were not sampled here) contains a distinct assemblage and whether this pattern varies geographically.
The assemblages of cultivated $D$. eriantha pastures were very unique, largely because of the absence of woody plants. Although studies in open grasslands in South Africa have shown very contrasting patterns of family dominance 
(Haddad et al. 2015; Jansen et al. 2013; Lotz et al. 1991; Van den Berg \& Dippenaar-Schoeman 1991), the dominance of Ammoxenidae in the cultivated $D$. eriantha pastures studied here is quite extreme $(66.15 \%)$. This could be attributed to the high abundance of Hodotermes mossambicus (Hagen, 1853) termites in the pastures, which are the sole prey of A. amphalodes (Petráková et al. 2015). Similarly, the high activity of Ranops sp. in this habitat (13.24\%) can be attributed to high activity densities of their mimetic model and possible prey ant, Anoplolepis custodiens (F. Smith, 1858) (Haddad 2012). Interestingly, these were the only two spider species with indicator values above $70.0 \%$, suggesting that the other species sampled had more general habitat preferences, were more strongly seasonal in occurrence or were too scarce to serve as meaningful indicators of particular habitats.

The ten species of mygalomorph trapdoor spiders collected in four months' sampling ( 9600 pitfall trap-days) is quite remarkable. This is higher than the eight species collected during nearly 22000 pitfall trap-days' sampling in open grasslands in the Erfenis Dam Nature Reserve (Haddad et al. 2015) and the five species collected in open grassland during 36500 trap-days' sampling in the Free State National Botanical Gardens (J.A. Neethling \& C.R. Haddad [University of the Free State] unpubl., August 2010 to May 2011), both within a radius of $70 \mathrm{~km}$ from Amanzi. This is probably because of the more structurally and topographically variable habitats sampled in the current study compared to open grasslands sampled in the latter two studies. The inclusion of open grassland habitats in the current study would likely have increased the trapdoor spider diversity at this site. For example, Calommata meridionalis Fourie, Haddad and Jocqué, 2011 (Atypidae) was not collected in this study but has been recorded from the other two sites (Fourie et al. 2011; Haddad et al. 2015). In addition, an unidentified Harpactira sp. (Theraphosidae) has also been collected from burrows and/or at night at all three localities, but has yet to be sampled using pitfall trapping.

Two faunistic records are of particular interest: the treetrapdoor genus Moggridgea (Migidae) is recorded from the Free State province for the first time (DippenaarSchoeman 2002; Dippenaar-Schoeman et al. 2010; Griswold 1987), with five male spiders sampled in very contrasting habitats (Appendix 1). This suggests that this species may occur in shrublands throughout central South Africa. This study also yielded the first records of Opiliones from the central Free State (Assamiidae: Polycoryphus asper Loman, 1902); all previous records of harvestmen in the province are from the eastern or southern fringes (Lotz 2002). Previously, this species was only known from the Kogelbeen caves in Northern Cape, Port Elizabeth in the Eastern Cape and on the Namibia-Angola border, and is thus widespread although scarce (Lotz 2009). Although only two specimens were collected in pitfall traps from the southern slope sites in this study, more than 20 additional specimens were collected from beneath large rocks on various hills at Amanzi, all on the southern slopes. Further studies are needed elsewhere in central South Africa to clarify the distribution and microhabitat preferences of these two arachnids.

\section{Conclusion}

This is the first study to investigate spider assemblages in shrubland, hill and pasture habitats in the Grassland Biome of the Free State, South Africa. Our results indicate that activity densities of spiders are lower in shrubland habitats than cultivated pastures and open grasslands previously sampled in central South Africa. Shrublands accommodate very different assemblages to pastures and grasslands, and therefore, conservation efforts for arachnids will benefit considerably from sampling a broader habitat diversity to identify potential indicator species and species of potential conservation importance.

\section{Acknowledgements}

Kobie Fourie is thanked for permission to conduct this study at Amanzi Private Game Reserve and for providing accommodation during the field work to the second author. Ansie Dippenaar-Schoeman (ARC - Plant Protection Research Institute, Pretoria) and Leon Lotz (National Museum, Bloemfontein) are thanked for identifications of some of the species. The Free State Department of Economic Development, Tourism and Environmental Affairs is thanked for collecting permits that made the study possible.

\section{Competing interests}

The authors declare that they have no financial or personal relationships that may have inappropriately influenced them in writing this article.

\section{Authors' contributions}

C.R.H. performed initial sorting of arthropod material, identified the arachnid material, performed the statistical analysis and wrote part of the manuscript. V.P.B. performed the vegetation analysis, conducted the field work, assisted with initial sorting of arthropod material and wrote part of the manuscript.

\section{Funding information}

This study was funded through a grant to the senior author from the National Research Foundation of South Africa in the Thuthuka programme (\#69017).

\section{References}

Bredenkamp, G.J. \& Van Rooyen, N., 1996, 'Dry Sandy Highveld Grassland', in A.B. Low \& A.G. Rebelo (eds.), Vegetation of South Africa, Lesotho and Swaziland, p. 41, Department of Environmental Affairs and Tourism, Pretoria.

Butler, V.P., 2017, 'Feeding ecology of the greater kudu (Tragelaphus strepsiceros) in the central Free State', Unpublished M.Sc dissertation, University of the Free State, Bloemfontein.

Butler, V.P. \& Haddad, C.R., 2011, 'Spider assemblages associated with leaf litter of three tree species in central South Africa (Arachnida: Araneae)', African Journal of Ecology 49, 301-310. https://doi.org/10.1111/j.1365-2028.2011.01265.x 
Carbutt, C., Tau, M., Stephens, A. \& Escott, B., 2011, 'The conservation status of temperate grasslands in southern Africa', Grassroots 11, 17-23.

Cardoso, P., Scharff, N., Gaspar, C.S., Henriques, S.S., Carvalho, R., Castro, P.H. et al., 2008, 'Rapid biodiversity assessment of spiders (Araneae) using semi-quantitative sampling: A case study in a Mediterranean forest', Insect Conservation and Diversity 1, 71-84. https://doi.org/10.1111/j.1752-4598.2007.00008.x

Chao, A., 1984, 'Nonparametric estimation of the number of classes in a population' Scandinavian Journal of Statistics 11, 265-270.

Chao, A. \& Jost, L., 2012, 'Coverage-based rarefaction and extrapolation: Standardizing samples by completeness rather than size', Ecology 93, 2533-2547. https://doi. org/10.1890/11-1952.1

Chao, A. \& Lee, S.M., 1992, 'Estimating the number of classes via sample coverage', Journal of the American Statistical Association 87, 210-217. https://doi.org/10.10 80/01621459.1992.10475194

Clarke, K.R., 1993, 'Non-parametric multivariate analyses of changes in community structure', Australian Journal of Ecology 18, 117-143. https://doi.org/10.1111/ j.1442-9993.1993.tb00438.x

Clarke, K.R. \& Warwick, R.M., 2001, Change in marine communities: An approach to statistical analysis and interpretation, 2nd edn., PRIMER-E, Plymouth.

Dippenaar-Schoeman, A.S., 2002, Baboon and trapdoor spiders of Southern Africa: An identification manual, Agricultural Research Council, Pretoria.

Dippenaar-Schoeman, A.S., Haddad, C.R., Foord, S.H., Lyle, R., Helberg, L., Mathebula, S. et al., 2010, First Atlas of the Spiders of South Africa (Arachnida: Araneae), ARC - Plant Protection Research Institute, Pretoria, pp. 1158.

Dippenaar-Schoeman, A.S., Haddad, C.R., Foord, S.H., Lyle, R., Lotz, L.N. \& Marais, P., 2015, 'South African National Survey of Arachnida (SANSA): Review of current knowledge, constraints and future needs for documenting spider diversity (Arachnida: Araneae)', Transactions of the Royal Society of South Africa 70 245-275. https://doi.org/10.1080/0035919X.2015.1088486

Dippenaar-Schoeman, A.S., Hamer, M. \& Haddad, C.R., 2011, 'Spiders (Arachnida: Araneae) of the vegetation layer of the Mkambati Nature Reserve, Eastern Cape South Africa', Koedoe 53(1), 1058. https://doi.org/10.4102/koedoe.v53i1.1058

Dufrene, M. \& Legendre, P., 1997, 'Species assemblages and indicator species: The need for a flexible asymmetrical approach', Ecological Monographs 67, 345-366. https://doi.org/10.2307/2963459

Foord, S.H., Dippenaar-Schoeman, A.S. \& Haddad, C.R., 2011, 'South African spider diversity: African perspectives on the conservation of a mega-diverse group' in $O$. Grillo \& G. Venora (eds.), Changing diversity in changing environment, pp. 163-182, Grillo \& G. Venora (eds.),
InTech Publishing, Rijeka.

Fourie, R., Haddad, C.R., Dippenaar-Schoeman, A.S. \& Grobler, A., 2013, 'Ecology of the plant-dwelling spiders (Arachnida: Araneae) of the Erfenis Dam Nature Reserve, South Africa', Koedoe 55(1), 1113. https://doi.org/10.4102/koedoe.v55i1.1113

Fourie, R., Haddad, C.R. \& Jocqué, R., 2011, 'A revision of the purse-web spider genus Calommata Lucas, 1837 (Araneae: Atypidae) in the Afrotropical Region', ZooKeys 95, 1-28. https://doi.org/10.3897/zookeys.95.745

Griswold, C.E., 1987, 'The African members of the trap-door spider family Migidae (Araneae: Mygalomorphae) 1: The genus Moggridgea O. P.-Cambridge, 1875', Annals of the Natal Museum 28, 1-118.

Haddad, C.R., 2005, 'Ecology of spiders (Arachnida: Araneae) inhabiting Themeda triandra Forskål grassland in semi-arid South Africa', Navorsinge van die Nasionale Museum, Bloemfontein 21, 25-36.

Haddad, C.R., 2012, 'Advances in the systematics and ecology of African Corinnidae spiders (Arachnida: Araneae), with emphasis on the Castianeirinae', Unpublished PhD thesis, University of the Free State, Bloemfontein.

Haddad, C.R. \& Dippenaar-Schoeman, A.S., 2002, 'The influence of mound structure on the diversity of spiders (Araneae) inhabiting the abandoned mounds of the snouted harvester termite Trinervitermes trinervoides (Sjöstedt)', Journal of Arachnology 30 , harvester termite Trinervitermes trinervoides (Sjostedt)', Journal of Arachnology 30,
403-408. https://doi.org/10.1636/0161-8202(2002)030[0403:TIOMSO]2.0.CO;2

Haddad, C.R. \& Dippenaar-Schoeman, A.S., 2006, 'Spiders (Arachnida: Araneae) inhabiting abandoned mounds of the snouted harvester termite Trinervitermes inhabiting abandoned mounds of the snouted harvester termite Trinervitermes trinervoides (Sjöstedt) (Isoptera: Termitidae: Nasutitermitinae) in the Free State, with notes on their biology', Navorsinge van die Nasionale Museum, Bloemfontein
22, 1-15.

Haddad, C.R., Dippenaar-Schoeman, A.S., Foord, S.H., Lotz, L.N. \& Lyle, R., 2013, 'The faunistic diversity of spiders (Arachnida: Araneae) of the Grassland Biome in South Africa', Transactions of the Royal Society of South Africa 68, 97-122. https://doi. org/10.1080/0035919X.2013.773267
Haddad, C.R., Foord, S.H., Fourie, R. \& Dippenaar-Schoeman, A.S., 2015, 'Effects of a fast-burning spring fire on the ground-dwelling spider assemblages (Arachnida: Araneae) in a central South African grassland habitat', African Zoology 50, 281-292. https://doi.org/10.1080/15627020.2015.1088400

Haddad, C.R., Honiball, A.S., Dippenaar-Schoeman, A.S., Slotow, R. \& Van Rensburg B.J., 2010, 'Spiders (Arachnida: Araneae) as indicators of elephant-induced habitat changes in the Maputaland Centre of Endemism, South Africa', African Journal of Ecology 48, 446-460. https://doi.org/10.1111/j.1365-2028.2009.01133.x

Hammer, Ø., Harper, D.A.T. \& Ryan, P.D., 2001, 'PAST - PAlaeontological STatistics', Palaeontologia Electronica 4, 1-33.

Janion-Scheepers, C., Measey, J., Braschler, B., Chown, S.L., Coetzee, L., Colville, J. et al., 2016, 'Soil biota in a megadiverse country: Current knowledge and future research directions in South Africa', Pedobiologia 59, 129-174. https://doi.org/10.1016/j. pedobi.2016.03.004

Jansen, R., Makaka, L., Little, I.T. \& Dippenaar-Schoeman, A.S., 2013, 'Response of ground-dwelling spider assemblages (Arachnida, Araneae) to montane grassland management practices in South Africa', Insect Conservation and Diversity 6 , 572-589. https://doi.org/10.1111/icad.12013

Lotz, L.N., 2002, 'The Opiliones (Arachnida) of the Free State Province, South Africa', Navorsinge van die Nasionale Museum, Bloemfontein 18, 161-188.

Lotz, L.N., 2009, 'Harvestmen (Arachnida: Opiliones) in southern Africa - An annotated catalogue with notes on distribution', Navorsinge van die Nasionale Museum, Bloemfontein 25, 1-46.

Lotz, L.N., Seaman, M.T. \& Kok, D.J., 1991, 'Surface-active spiders (Araneae) of a site in semi-arid central South Africa', Navorsinge van die Nasionale Museum, Bloemfontein 7, 530-540.

Low, A.B. \& Rebelo, A.G., 1996, Vegetation of South Africa, Lesotho and Swaziland, Department of Environmental Affairs and Tourism, Pretoria.

McGeoch, M.A., Van Rensburg, B.J. \& Botes, A., 2002, 'The verification and application of bioindicators: A case study of dung beetles in a savanna ecosystem', Journal of Applied Ecology 39, 661-672. https://doi.org/10.1046/j.1365-2664.2002. 00743.x

Mucina, L. \& Rutherford, M.C., 2006, The vegetation of South Africa, Lesotho and Swaziland, Strelitzia 19, South African National Biodiversity Institute, Pretoria.

Neethling, J.A. \& Haddad, C.R., 2013, 'Arboreal spider assemblages associated with four tree species in the Grassland Biome of central South Africa (Arachnida: Araneae)', Transactions of the Royal Society of South Africa 68, 123-131. https:// doi.org/10.1080/0035919X.2013.806374

O'Connor, T.G. \& Kuyler, P., 2005, National Grasslands Initiative: Identification of compatible land uses for maintaining compatible biodiversity integrity, Unpublished report, South African National Biodiversity Institute, Pretoria.

Petráková, L., Líznarová, E., Pekár, S., Haddad, C.R., Sentenská, L. \& Symondson, W.O.C. 2015, 'Discovery of a monophagous true predator, a specialist termite-eating spider (Araneae: Ammoxenidae)', Scientific Reports 5, 14013. https://doi.org/10.1038/ srep14013

Rutherford, M.C. \& Westfall, R.H., 1994, 'Biomes of southern Africa: an objective characterization', Memoirs of the Botanical Survey of South Africa 6, 1-94.

Scharff, N., Coddington, J.A., Griswold, C.E., Hormiga, G. \& Bjorn, P., 2003, 'When to quit? Estimating spider species richness in a northern European deciduous forest', Journal of Arachnology 31, 246-273. https://doi.org/10.1636/0161-8202(2003) Journal of Arachnology 31,

Sørensen, L.I., Coddington, J.A. \& Scharff, N.J., 2002, 'Inventorying and estimating subcanopy spider diversity using semiquantitative sampling methods in an Afromontane forest', Environmental Entomology 31, 319-330. https://doi.org/10 Afromontane forest', Enviro

Van den Berg, A. \& Dippenaar-Schoeman, A.S., 1991, 'Ground-living spiders from an area where the harvester termite Hodotermes mossambicus occurs in South Africa', Phytophylactica 23, 247-253.

Van Rensburg, B.J., McGeoch, M.A., Chown, S.L. \& Van Jaarsveld, A.S., 1999, 'Conservation of heterogeneity among dung beetles in the Maputaland Centre of Endemism, South Africa', Biological Conservation 88, 145-153. https://doi.org/ 10.1016/S0006-3207(98)00109-8

Wessels, K.J., Reyers, B., Van Jaarsveld, A.S. \& Rutherford, M.C., 2003, 'Identification of potential conflict areas between land transformation and biodiversity conservation in north-eastern South Africa', Agriculture, Ecosystems and Environment 95, 157-178. https://doi.org/10.1016/S0167-8809(02)00102-0 


\section{Appendix 1}

TABLE 1-A1: Ground-dwelling spiders collected by pitfall trapping from eight habitats in the Amanzi Private Game Reserve.

\begin{tabular}{|c|c|c|c|c|c|c|c|c|c|c|}
\hline Ground-dwelling spiders & B & C & $\mathbf{D}$ & $\mathbf{N}$ & $\mathbf{P}$ & $S$ & $T$ & $\mathbf{v}$ & Total & $\%$ \\
\hline \multicolumn{11}{|l|}{ AGELENIDAE } \\
\hline Agelena australis Simon, 1896 & 7 & 0 & 0 & 0 & 1 & 5 & 2 & 3 & 18 & 0.60 \\
\hline \multicolumn{11}{|l|}{ AMAUROBIIDAE } \\
\hline Amaurobiidae sp. 1 indet. $\dagger$ & 13 & 1 & 1 & 4 & 5 & 0 & 1 & 1 & 26 & 0.87 \\
\hline Amaurobiidae sp. 2 indet. $\dagger$ & 0 & 0 & 0 & 1 & 0 & 10 & 0 & 0 & 11 & 0.37 \\
\hline \multicolumn{11}{|l|}{ AMMOXENIDAE } \\
\hline Ammoxenus amphalodes Dippenaar \& Meyer, 1980 & 37 & 979 & 39 & 4 & 4 & 59 & 32 & 64 & 1218 & 40.85 \\
\hline \multicolumn{11}{|l|}{ ARANEIDAE } \\
\hline Hypsosinga lithyphantoides Caporiacco, 1947 & 0 & 0 & 0 & 0 & 0 & 1 & 0 & 1 & 2 & 0.07 \\
\hline \multicolumn{11}{|l|}{ CAPONIIDAE } \\
\hline Caponia hastifera Purcell, 1904 & 3 & 1 & 1 & 1 & 8 & 7 & 6 & 8 & 35 & 1.17 \\
\hline \multicolumn{11}{|l|}{ CLUBIONIDAE } \\
\hline Clubiona sp. $1 \uparrow$ & 1 & 0 & 0 & 0 & 0 & 0 & 0 & 1 & 2 & 0.07 \\
\hline \multicolumn{11}{|l|}{ CORINNIDAE } \\
\hline Cambalida dippenaarae Haddad, 2012 & 0 & 0 & 0 & 0 & 0 & 5 & 0 & 0 & 5 & 0.17 \\
\hline Graptartia mutillica Haddad, 2004 & 1 & 2 & 0 & 0 & 1 & 0 & 0 & 3 & 7 & 0.23 \\
\hline
\end{tabular}

\section{CTENIZIDAE}

$\begin{array}{llllllllll}\text { Stasimopus minor Hewitt, } 1915 & 0 & 1 & 0 & 0 & 0 & 0 & 1 & 1 & 3\end{array}$

Stasimopus oculatus Pocock, 1897

\section{CYRTAUCHENIIDAE}

Ancylotrypa dreyeri (Hewitt, 1915):

Ancylotrypa nigriceps (Purcell, 1902) $\ddagger$

Ancylotrypa sp. 3

Ancylotrypa sp. 4

Homostola sp.

DICTYNIDAE

Dictynidae sp. indet.

GNAPHOSIDAE

Aneplasa sp.

Asemesthes lineatus Tucker, 1923\%

Asemesthes oconnori Tucker, 1923:

Asemesthes purcelli Tucker, 1923:

Camillina cordifera (Tullgren, 1910)

Drassodes ereptor Purcell, 1907

Drassodes sp. 2

Drassodes sp. 3

Drassodes sp. 4

Drassodes sp. 5

Eilica lotzi FitzPatrick, 2002

Leptodrassex sp. $1 \dagger$

Leptodrassex sp. $2 \dagger$

Megamyrmaekion schreineri Tucker, 1923:

Micaria sp. $1 \dagger$

Micaria sp. $2 \dagger$

Pterotricha auris (Tucker, 1923)

Pterotricha sp. 2\$

Scotophaeus sp.

Setaphis browni (Tucker, 1923)

Setaphis subtilis (Simon, 1897)

Trephopoda aplanita (Tucker, 1923):

Trephopoda kannemeyeri (Tucker, 1923):

Trephopoda sp. 3

Xerophaeus appendiculatus Purcell, 1907

Xerophaeus vickermani Tucker, 1923

Zelotes corrugatus (Purcell, 1907)

Zelotes frenchi Tucker, 1923

Zelotes fuligineus (Purcell, 1907)

Zelotes humilis (Purcell, 1907)

Zelotes sclateri Tucker, 1923

Zelotes scrutatus (O.P. Cambridge, 1872)

$\begin{array}{cccccccccc}0 & 0 & 0 & 0 & 0 & 0 & 0 & 4 & 4 & 0.13 \\ 1 & 0 & 0 & 0 & 0 & 0 & 1 & 0 & 2 & 0.07 \\ 4 & 0 & 0 & 0 & 1 & 8 & 0 & 0 & 13 & 0.44 \\ 1 & 0 & 0 & 0 & 0 & 0 & 0 & 0 & 1 & 0.03 \\ 0 & 0 & 0 & 0 & 0 & 0 & 0 & 1 & 1 & 0.03\end{array}$

\begin{tabular}{|c|c|c|c|c|c|c|c|c|c|}
\hline 0 & 0 & 0 & 0 & 1 & 0 & 0 & 0 & 1 & 0.03 \\
\hline 19 & 1 & 7 & 0 & 0 & 0 & 0 & 0 & 27 & 0.91 \\
\hline 2 & 3 & 0 & 0 & 0 & 0 & 0 & 0 & 5 & 0.17 \\
\hline 0 & 0 & 0 & 2 & 0 & 0 & 0 & 0 & 2 & 0.07 \\
\hline 0 & 0 & 0 & 1 & 0 & 0 & 0 & 0 & 1 & 0.03 \\
\hline 11 & 18 & 1 & 5 & 6 & 6 & 4 & 0 & 51 & 1.71 \\
\hline 0 & 0 & 1 & 0 & 0 & 0 & 0 & 0 & 1 & 0.03 \\
\hline 3 & 46 & 0 & 0 & 3 & 0 & 3 & 1 & 56 & 1.88 \\
\hline 20 & 41 & 10 & 4 & 1 & 2 & 12 & 8 & 98 & 3.29 \\
\hline 1 & 1 & 1 & 0 & 3 & 0 & 0 & 0 & 6 & 0.20 \\
\hline 0 & 1 & 0 & 0 & 0 & 0 & 0 & 0 & 1 & 0.03 \\
\hline 0 & 1 & 0 & 0 & 0 & 0 & 0 & 0 & 1 & 0.03 \\
\hline 1 & 1 & 0 & 0 & 1 & 1 & 0 & 0 & 4 & 0.13 \\
\hline 14 & 18 & 0 & 0 & 0 & 0 & 1 & 0 & 33 & 1.11 \\
\hline 0 & 0 & 1 & 0 & 0 & 0 & 0 & 0 & 1 & 0.03 \\
\hline 1 & 2 & 0 & 1 & 1 & 0 & 0 & 0 & 5 & 0.17 \\
\hline 0 & 0 & 0 & 0 & 0 & 0 & 0 & 2 & 2 & 0.07 \\
\hline 0 & 1 & 0 & 0 & 2 & 1 & 1 & 2 & 7 & 0.23 \\
\hline 0 & 0 & 0 & 0 & 0 & 0 & 0 & 1 & 1 & 0.03 \\
\hline 0 & 0 & 0 & 0 & 1 & 0 & 0 & 0 & 1 & 0.03 \\
\hline 0 & 0 & 0 & 10 & 0 & 0 & 0 & 0 & 10 & 0.34 \\
\hline 8 & 13 & 6 & 22 & 1 & 1 & 22 & 3 & 76 & 2.55 \\
\hline 0 & 4 & 0 & 0 & 0 & 0 & 0 & 2 & 6 & 0.20 \\
\hline 0 & 1 & 0 & 0 & 0 & 0 & 0 & 0 & 1 & 0.03 \\
\hline 1 & 1 & 0 & 0 & 0 & 0 & 0 & 0 & 2 & 0.07 \\
\hline 2 & 0 & 0 & 0 & 0 & 0 & 0 & 0 & 2 & 0.07 \\
\hline 0 & 0 & 0 & 1 & 0 & 0 & 0 & 1 & 2 & 0.07 \\
\hline 2 & 0 & 0 & 0 & 0 & 0 & 0 & 0 & 2 & 0.07 \\
\hline 0 & 0 & 0 & 0 & 0 & 7 & 0 & 0 & 7 & 0.23 \\
\hline 2 & 11 & 1 & 0 & 0 & 0 & 0 & 9 & 23 & 0.77 \\
\hline 35 & 14 & 1 & 2 & 17 & 8 & 10 & 22 & 109 & 3.66 \\
\hline 5 & 5 & 0 & 4 & 3 & 0 & 1 & 0 & 18 & 0.60 \\
\hline 9 & 9 & 11 & 23 & 0 & 1 & 13 & 7 & 73 & 2.45 \\
\hline
\end{tabular}


TABLE 1-A1 (Continues...): Ground-dwelling spiders collected by pitfall trapping from eight habitats in the Amanzi Private Game Reserve.

\begin{tabular}{llllllll}
\hline Ground-dwelling spiders & B & C & D & N & P & S & T
\end{tabular}

\section{HAHNIIDAE}

Hahnia tabulicola Simon, 1898

$\begin{array}{llllllllll}0 & 0 & 2 & 0 & 0 & 0 & 0 & 0 & 2 & 0.07 \\ 0 & 0 & 1 & 0 & 0 & 0 & 0 & 0 & 1 & 0.03\end{array}$

Hahnia sp. 2

\section{HERSILIIDAE}

Tyrotama australis (Simon, 1893)

$\begin{array}{llll}0 & 0 & 0 & 3\end{array}$

\section{IDIOPIDAE}

Idiops sp.

Segregara sp. 1

$\begin{array}{llllllllll}0 & 0 & 1 & 0 & 0 & 0 & 1 & 0 & 2 & 0.07 \\ 3 & 0 & 2 & 1 & 0 & 1 & 0 & 0 & 7 & 0.23\end{array}$

\section{LINYPHIIDAE}

Linyphiidae sp. indet.

\section{LYCOSIDAE}

Allocosa schoenlandi (Pocock, 1900):

Allocosa tuberculipalpa (Caporiacco, 1940)

Amblyothele albocincta Simon, 1910

Evippomma squamulatum (Simon, 1898)

Geolycosa sp.

Hippasa australis Lawrence, 1927

Hogna bimaculata (Purcell, 1903) $\ddagger$

Hogna transvaalica (Simon, 1898) $\ddagger$

Hogna sp. 3

Pardosa crassipalpis Purcell, 1904

Pardosa sp. 2

Proevippa sp. 1

Proevippa sp. 2

Trabea purcelli Roewer, 1951

Zenonina mystacina Simon, 1898

\section{MIGIDAE}

Moggridgea sp. $\dagger$

\section{OONOPIDAE}

Dysderina sp.‡

$0 \quad 0$

$0 \quad 0$

0

\section{Opopaea mattica Simon, 1893 \\ ORSOLOBIDAE}

Afrilobus sp.

OXYOPIDAE

Oxyopes sp. 1

Oxyopes sp. 2

\section{PALPIMANIDAE}

Palpimanus sp. $1 \dagger$

Palpimanus sp. $2 \dagger$

Palpimanus sp. $3 \dagger$

\section{PHILODROMIDAE}

Hirriusa arenacea (Lawrence, 1927)

Philodromus sp. 1

Thanatus vulgaris Simon, 1870

Thanatus sp. 2

Tibellus minor Lessert, 1919

\section{PHRUROLITHIDAE}

Orthobula sp. $\dagger$

\section{PHYXELIDIDAE}

Vidole sothoana Griswold, 1990 PRODIDOMIDAE

\section{Austrodomus sp. $\dagger$}

Theuma capensis Purcell, 1907

Theuma maculata Purcell, 1907\$

\section{SALTICIDAE}

Evarcha prosimilis Wesołowska \& Cumming, 2008

Evarcha sp. $\dagger$

Heliophanus debilis Simon, 1901

Heliophanus pistaciae Wesołowska, 2003

Heliophanus sp.

Icius insolidus (Wesołowska, 1999)

Langona hirsuta Haddad \& Wesołowska, 2011

$\begin{array}{ll}0 & 2 \\ 0 & 5 \\ 0 & 1 \\ 0 & 0 \\ 1 & 0 \\ 0 & 0 \\ 0 & 0 \\ 0 & 0 \\ 1 & 0 \\ 0 & 0 \\ 0 & 0 \\ 0 & 23 \\ 0 & 6 \\ 0 & 0 \\ 0 & 0\end{array}$

$\begin{array}{lllll}0 & 0 & 1 & 1 & 0.03\end{array}$

0.03 
TABLE 1-A1 (Continues...): Ground-dwelling spiders collected by pitfall trapping from eight habitats in the Amanzi Private Game Reserve.

\begin{tabular}{|c|c|c|c|c|c|c|c|c|c|c|}
\hline Ground-dwelling spiders & B & $\mathrm{C}$ & D & $\mathbf{N}$ & $\mathbf{P}$ & $\mathbf{S}$ & $\mathbf{T}$ & $\mathbf{v}$ & Total & $\%$ \\
\hline Langona warchalowskii Wesołowska, 2007 & 0 & 0 & 0 & 0 & 5 & 0 & 0 & 0 & 5 & 0.17 \\
\hline Mogrus mathisi (Berland \& Millot, 1941) & 0 & 0 & 0 & 0 & 0 & 0 & 0 & 1 & 1 & 0.03 \\
\hline Nigorella hirsuta Wesołowska, 2009 & 2 & 0 & 0 & 0 & 0 & 0 & 0 & 1 & 3 & 0.10 \\
\hline Pellenes bulawayoensis Wesołowska, 1999 & 23 & 8 & 16 & 13 & 2 & 5 & 5 & 10 & 82 & 2.75 \\
\hline Pellenes geniculatus (Simon, 1868) & 2 & 1 & 8 & 1 & 0 & 0 & 0 & 0 & 12 & 0.40 \\
\hline Pellenes tharinae Wesołowska, 2006 & 2 & 0 & 7 & 9 & 0 & 0 & 1 & 0 & 19 & 0.64 \\
\hline Phlegra etosha Logunov \& Azarkina, 2006 & 0 & 0 & 0 & 12 & 1 & 0 & 0 & 0 & 13 & 0.44 \\
\hline Phlegra karoo Wesołowska, 2006 & 36 & 21 & 12 & 5 & 4 & 1 & 3 & 27 & 109 & 3.66 \\
\hline Pignus simoni (Peckham \& Peckham, 1903) & 0 & 0 & 0 & 0 & 0 & 0 & 1 & 0 & 1 & 0.03 \\
\hline Thyene thyenioides (Lessert, 1925) & 0 & 0 & 0 & 0 & 0 & 0 & 1 & 0 & 1 & 0.03 \\
\hline
\end{tabular}

\section{SEGESTRIIDAE}

Ariadna corticola Lawrence, 1952

$\begin{array}{lllllllll}0 & 0 & 0 & 0 & 0 & 1 & 0 & 0 & 1\end{array}$

\section{SELENOPIDAE}

Anyphops immaculatus (Lawrence, 1940) $\quad \begin{array}{lllllllll}0 & 0 & 0 & 0 & 0 & 1 & 0 & 0 & 1\end{array}$

\section{SPARASSIDAE}

Pseudomicrommata longipes (Bösenberg \& Lenz, 1895)

$0 \quad 0$

\section{THERIDIIDAE}

Dipoena sp. $\dagger$

Euryopis sp. $\dagger$

Theridiidae sp. indet.

\section{THOMISIDAE}

Heriaeus allenjonesi Van Niekerk \& Dippenaar-Schoeman, 2013

Simorcus lotzi Van Niekerk \& Dippenaar-Schoeman, 2010

Stiphropus sp.†

Thomisops sulcatus Simon, 1895

Tmarus sp.

Xysticus natalensis Lawrence, 1938

$\begin{array}{ll}0 & 1 \\ 0 & 2 \\ 0 & 0\end{array}$

$0 \quad 0$

0

0

0

0

1

$1 \quad 0.03$

\section{TRACHELIDAE}

Poachelas striatus Haddad \& Lyle, 2008

Thysanina absolvo Lyle \& Haddad, 2006

\section{ZODARIIDAE}

\begin{tabular}{|c|c|c|c|c|c|c|c|c|c|c|}
\hline Chariobas sp. $\dagger$ & 0 & 0 & 0 & 0 & 0 & 0 & 1 & 0 & 1 & 0.03 \\
\hline Cydrela sp. $1 \dagger$ & 0 & 0 & 0 & 2 & 0 & 0 & 0 & 0 & 2 & 0.07 \\
\hline Cydrela sp. $2 \dagger$ & 1 & 0 & 1 & 0 & 0 & 0 & 1 & 1 & 4 & 0.13 \\
\hline Diores femoralis Jocqué, 1990 & 0 & 9 & 0 & 0 & 0 & 0 & 3 & 0 & 12 & 0.40 \\
\hline Diores poweri Tucker, 1920 & 0 & 1 & 0 & 1 & 30 & 0 & 1 & 1 & 34 & 1.14 \\
\hline Palfuria sp. $\dagger$ & 1 & 18 & 2 & 0 & 11 & 1 & 3 & 12 & 48 & 1.61 \\
\hline Ranops sp. $\dagger$ & 9 & 196 & 0 & 2 & 8 & 0 & 1 & 4 & 220 & 7.38 \\
\hline Zodariinae sp. & 1 & 0 & 0 & 0 & 0 & 0 & 0 & 0 & 1 & 0.03 \\
\hline Total & 296 & 1480 & 156 & 177 & 183 & 276 & 161 & 253 & 2982 & 100.00 \\
\hline
\end{tabular}

Habitat abbreviations: B, Searsia burchellii closed evergreen shrubland; C, cultivated Digitaria eriantha pastures; D, freshwater dam; N, Olea europaea closed evergreen shrubland on northern slopes of hill; P, O. europaea closed evergreen shrubland on plateau of hill; S, O. europaea closed evergreen shrubland on southern slope of hill; T, Tarchonanthus camphoratus closed evergreen shrubland; V, Vachellia karroo open deciduous shrubland.

$\dagger$, possible new species; $\$$, uncertain identification. 